\title{
Distributed Generation: Testing and Application in Mission Critical Settings and Transmission, Siting, and Metrics Models Research
}

\section{Final Technical Report}

\author{
Submitted by \\ Michelle New, Director \\ Research and Grants \\ September 2006
}

DOE Award Number: DE-FC36-02G012016

\author{
National Association of State Energy Officials \\ 1414 Prince Street, Suite 200 \\ Alexandria, VA 22314 \\ (703) 299-8800
}

Garry Ott

Project Engineer

Columbia Boulevard Wastewater

Treatment Plant

City of Portland Environmental

Services

5001 North Columbia Blvd.

Portland, Oregon 97203

(503) 823-2498
Richard Sedano

Principal

The Regulatory Assistance Project

50 State Street

Montpelier, Vermont 05602

(802) 223-8199 


\section{DISCLAIMER}

This report was prepared as an account of work sponsored by an agency of the U.S. government. Neither the United States Government nor any agency thereof, nor any of their employees, makes any warranty, express or implied, or assumes any legal liability or responsibility for the accuracy, completeness, or usefulness of any information, apparatus, product, or process disclosed, or represents that its use would not infringe privately owned rights. Reference herein to any specific commercial product, process, or service by trade name, trademark, manufacturer, or otherwise does not necessarily constitute or imply its endorsement, recommendation, or favoring by the U.S.

government or any agency thereof. The views and opinions of authors expressed herein do not necessarily state or reflect those of the U.S. government or any agency thereof. 


\section{Table of Contents}

Executive Summary

Task 1

Task 2

Task 3

Conclusion
Page 4

Pages 5 - 15

Pages 15 - 18

Pages 18 - 22

Page 23 


\section{Executive Summary}

The Distributed Generation: Testing and Application in Mission Critical Settings and Transmission, Siting, and Metrics Models Research grant has been in place for several years and has accomplished all the objectives and deliverables that were originally set forth in the proposal. The National Association of State Energy Officials (NASEO), the City of Portland, OR, Bureau of Environmental Services and the Regulatory Assistance Project (RAP) have been able to successfully monitor and evaluate DG applications in a wastewater treatment plant environment, develop a metrics model for new voluntary DG guidelines that could be used as a prototype, and through outreach and education venues provide the results of these projects to state, professional, and national organizations and their members addressing similar issues.

This project had three specific tasks associated with it:

1. Field Research and Testing

2. Metrics/Verification Model for DG Guidelines

\section{Northeastern Transmission/Siting Data Research}

Each task had its own set of challenges and lessons learned but overall there were many successes that will serve as learning opportunities in these technology areas. Continuing to share the outcomes of this project with a wider audience will be beneficial for all those involved in distributed generation and combined heat and power projects. 


\section{Task 1}

\section{Portland, Oregon DG Field Research and Testing}

\section{Project Overview}

The Portland field research and testing project was to conduct testing, monitoring, and verification activities associated with five generation units at an essential services facility in Portland, Oregon. The generation units include a fuel cell and four microturbines installed at a wastewater treatment facility. All units use anaerobic digester gas as a fuel source and operate in a combined heat and power mode recovering waste heat and using it to heat the plant itself. Engineers at the Columbia Boulevard Wastewater Treatment Plant worked with NASEO and the Oregon Department of Energy (ODOE) on this project. The purpose of the project was to gather important installation, operating, and maintenance data in order to present information that was gathered in a real-world working environment. The results of this project were disseminated to the energy community as a means of raising visibility of distributed generation as a successful primary and back-up_source of power.

\section{Site Description}

The Columbia Boulevard Wastewater Treatment Plant (CBWTP) in Portland, Oregon is the largest water treatment facility in the state. Operated by the Bureau of Environmental Services of the City of Portland, the plant treats an average of 80-90 million gals/day of sewage. The plant is the collection point for hundreds of miles of sewer pipe throughout the city powered by dozens of pumping stations. The plant takes the wastewater through several processing steps before returning clean water to the Columbia River. Left behind are tons of bio-solids that are themselves treated extensively before being dried and removed for use as a fertilizer.

A key part of the bio-solids processing are anaerobic digesters that use the action of bacteria to break down the solids and in the process produce a combustible gas composed primarily of methane and carbon dioxide (600 Btu/scf).

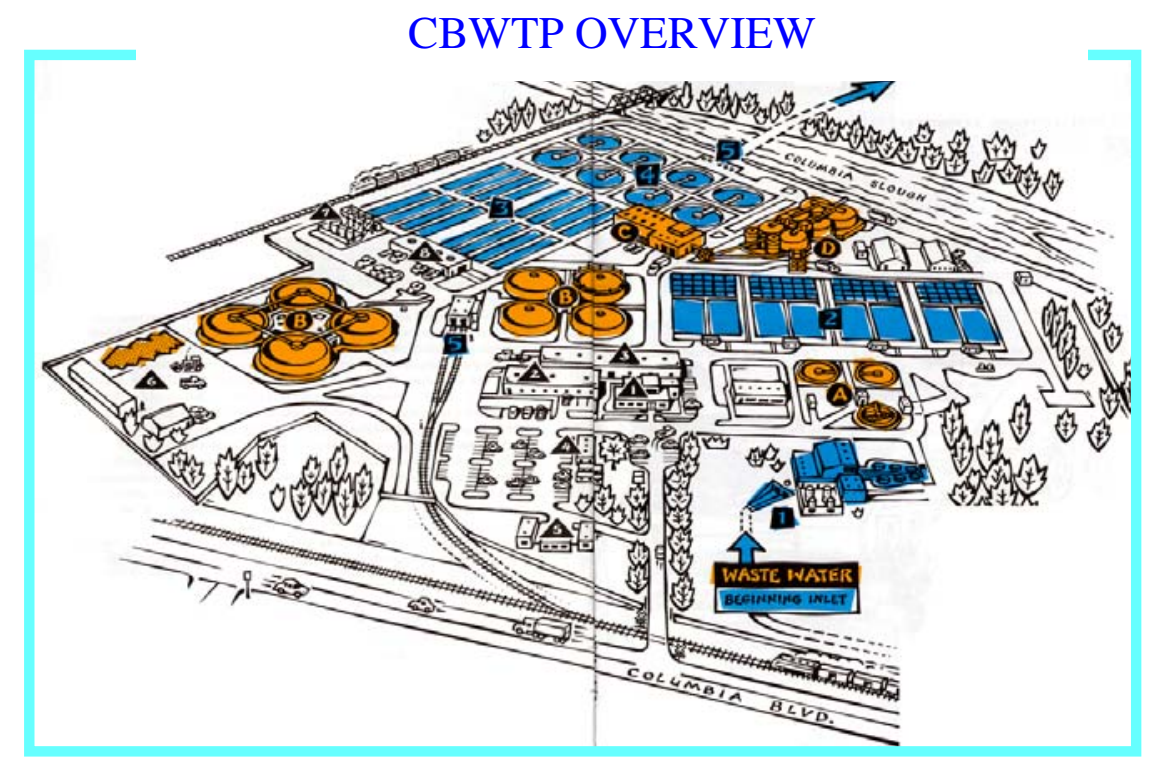

Solids

Fluids 
In 1993 Portland became the first U.S. city to adopt a strategy to reduce climate change through reduction in the production of carbon dioxide from combustion of fossil fuels. One of the recommendations contained in that strategy was to find ways to effectively utilize the anaerobic digester gas (ADG) produced at the plant.

\section{Fuel Cell}

In late 1999, a $200 \mathrm{~kW}$ fuel cell that converts biogas into electrical energy was installed. The CBWTP fuel cell was the first installation in the western United States of a fuel cell running on wastewater anaerobic digester gas and only the third such system in the nation. The fuel cell is a phosphoric acid fuel cell manufactured by ONSI Corporation (now United Technologies Corporation, the parent company of ONSI) with a total cost of $\$ 1.3$ million. The City of Portland received a \$200,000 grant for the fuel cell from the U.S. Department of Defense, as well as financial support from the Oregon Department of Energy, and the Fuel Cell Climate Change Program.

The plant's fuel cell extracts hydrogen from the digester gas, then combines the hydrogen and oxygen to produce water and electricity. An Inverter changes the direct current into alternating current, which is then fed into the plant power grid. The estimated electrical output of the fuel cell is about $175 \mathrm{~kW} / \mathrm{h}$ - enough electricity to power 125 homes. The treatment plant uses this energy as a primary source for powering its communications infrastructure. By producing its own electricity, the City of Portland estimated savings of approximately $\$ 60,000$ a year in energy costs.

\section{CBWTP 200kW Fuel Cell}

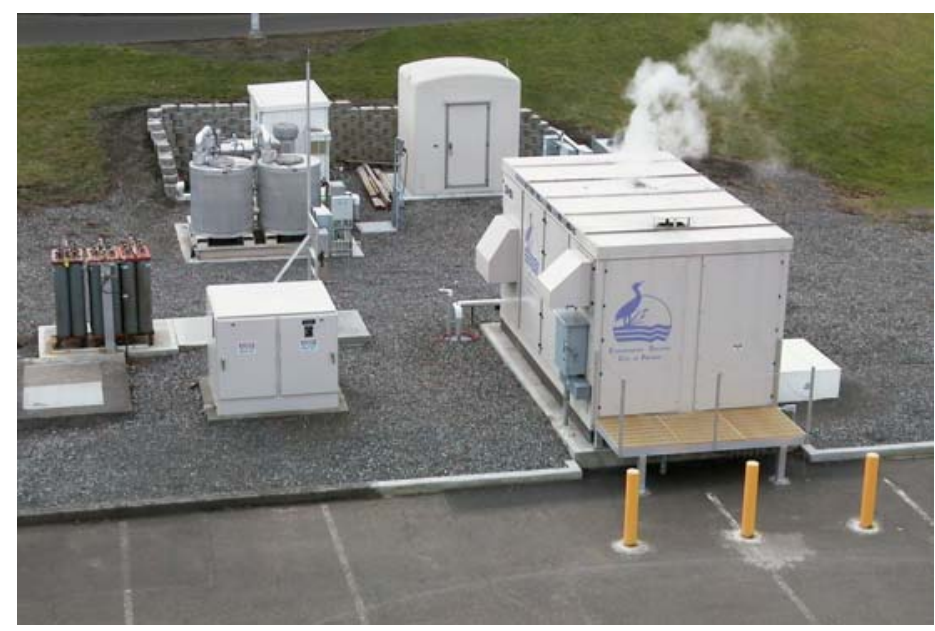

Fuel cell statistics:

Type: ONSI model PC25

Dimensions: $10^{\prime}$ x $10^{\prime}$ x $18^{\prime} / 40,000$ lbs.

Fuel: Anaerobic Digester

Electrical: $200 \mathrm{~W} \mathrm{k} / 235 \mathrm{KVA}$ (-20 to $110 \mathrm{~F}$, up to $500 \mathrm{ft}$.) $-480 / 277$ Volt, $60 \mathrm{~Hz} / 400 / 230$ Volt. $50 \mathrm{~Hz}$

Electrical Efficiency: 38\%

Heat Rate: 9,900 Btu/kWHr

Single-Walled Hex

Overall Fuel Cell Efficiency: 78\%

Grid connected 


\section{Operating and Maintenance Data on Fuel Cell}

The fuel cell was placed (dedicated) in service on July 19, 1999 with the following initial parameters:

- Cumulative operating hours:

- Cumulative Mega-Watt Hours delivered:

- Cumulative fuel consumed SCF (Standard Cubic Feet): 58643

SUMMARY OF FIVE YEAR OPERATING DATA

\begin{tabular}{|c|c|c|c|c|c|c|c|}
\hline Year & $\begin{array}{c}\text { Operating } \\
\text { Time }\end{array}$ & $\begin{array}{c}\text { Operational } \\
\text { Up-time } \\
(\%)\end{array}$ & $\begin{array}{c}\text { Average 5- } \\
\text { year } \\
\text { Operating } \\
\text { Up-time }\end{array}$ & $\begin{array}{c}\text { Actual Grid } \\
\text { MWh } \\
\text { Delivered }\end{array}$ & $\begin{array}{c}\text { Avoided } \\
\text { Cost } \\
\text { (Energy } \\
\text { savings) }\end{array}$ & $\begin{array}{c}\text { 5- year } \\
\text { Grid } \\
\text { MWh } \\
\text { Delivered }\end{array}$ & $\begin{array}{c}\text { 5-year } \\
\text { Avoided } \\
\text { Cost } \\
\text { (Energy } \\
\text { Savings) }\end{array}$ \\
\hline $1999-2000$ & $6,166 \mathrm{hrs}$ & $70.0 \%$ & & 901.0 & $\$ 58,565$ & & \\
\hline $2000-2001$ & $6,858 \mathrm{hrs}$ & $96.9 \%$ & & 871.6 & $\$ 56,654$ & & \\
\hline $2001-2002$ & $6,474 \mathrm{hrs}$ & $74.0 \%$ & & 824.4 & $\$ 53,586$ & & \\
\hline $2002-2003$ & $6,031 \mathrm{hrs}$ & $69,0 \%$ & & 766.5 & $\$ 47,872$ & & \\
\hline $2003-2004$ & $6,031 \mathrm{hrs}$. & $69.0 \%$ & & 766.5 & $\$ 47,872$ & & \\
\hline & & & $75.8 \%$ & & & 4,130 & $\$ 264,549$ \\
\hline
\end{tabular}

\section{OPERATING TIME}

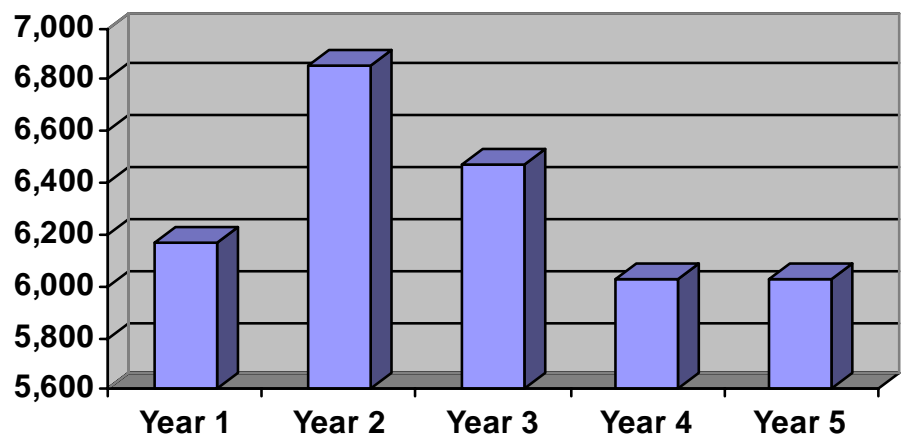

Over the five-year period, peak-operating time was in year 2 when the operational up time was $96.9 \%$.
4,130 MWh were delivered to the grid from 1999-2004, an average of 826 MWh per year.

\section{MWh DELIVERED TO GRID}

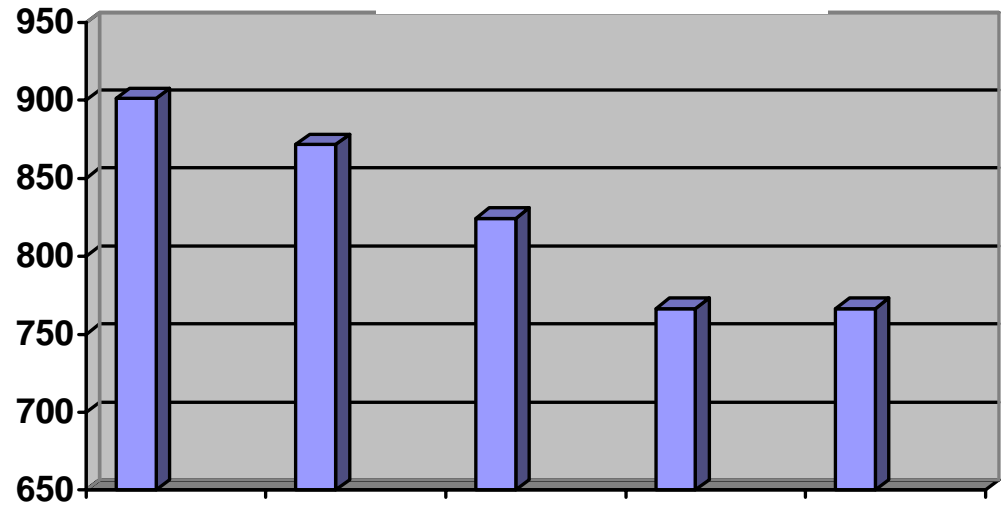




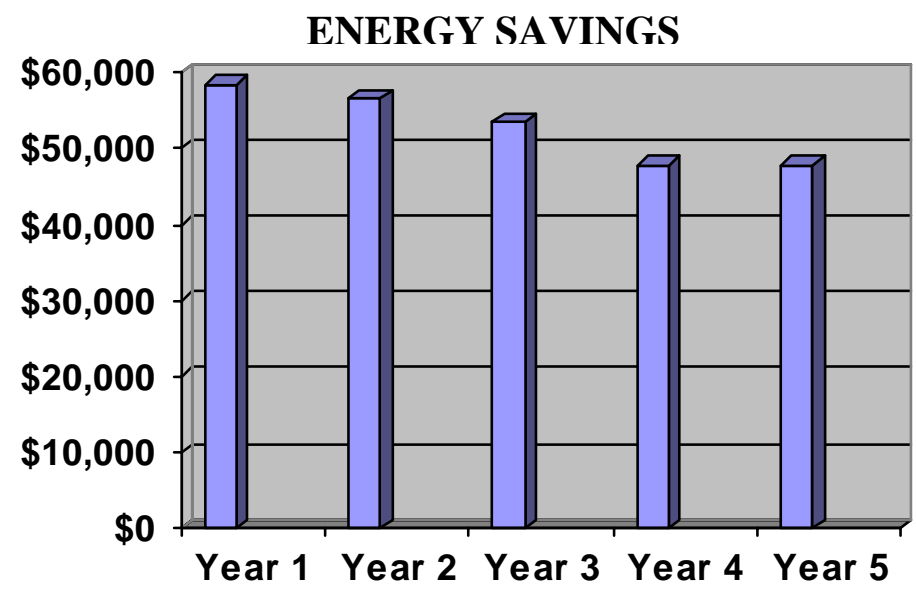

Over the 5 year period, avoided cost (energy savings) averaged \$52,909; approximately $\$ 8,000$ per year less than the original estimate of $\$ 60,000$ per year in energy cost savings.

\section{Maintenance Costs}

\section{SUMMARY OF FIVE YEAR MAINTENANCE COSTS (Fuel Cell)}

\begin{tabular}{|l|l|l|l|l|l|l|}
\hline $\begin{array}{l}\text { Cost } \\
\text { Categories }\end{array}$ & Year 1 & Year 2 & Year 3 & Year 4 & Year 5 & Total \\
\hline $\begin{array}{l}\text { Maintenance } \\
\text { Material } \\
\text { Labor }\end{array}$ & $\$ 8,768.36$ & $\$ 16,284.75$ & $\$ 24,444.53$ & $\$ 24,500$ & $\$ 24,329$ & $\$ 98,326.64$ \\
\hline $\begin{array}{l}\text { Start up } \\
\text { costs } \\
\text { Material } \\
\text { Labor }\end{array}$ & $\$ 3,301.28$ & $\$ 18,291.00$ & $\$ 16,416.10$ & $\$ 12,320$ & $\$ 12,000$ & $\$ 68,328.38$ \\
\hline $\begin{array}{l}\text { Parts } \\
\text { replacement } \\
\text { Material } \\
\text { Labor }\end{array}$ & & & & & & \\
\hline TOTAL & & & & & & $\$ 3,533.10$ \\
\hline
\end{tabular}

\section{Major Components of 5-Year}

\section{Maintenance Costs}

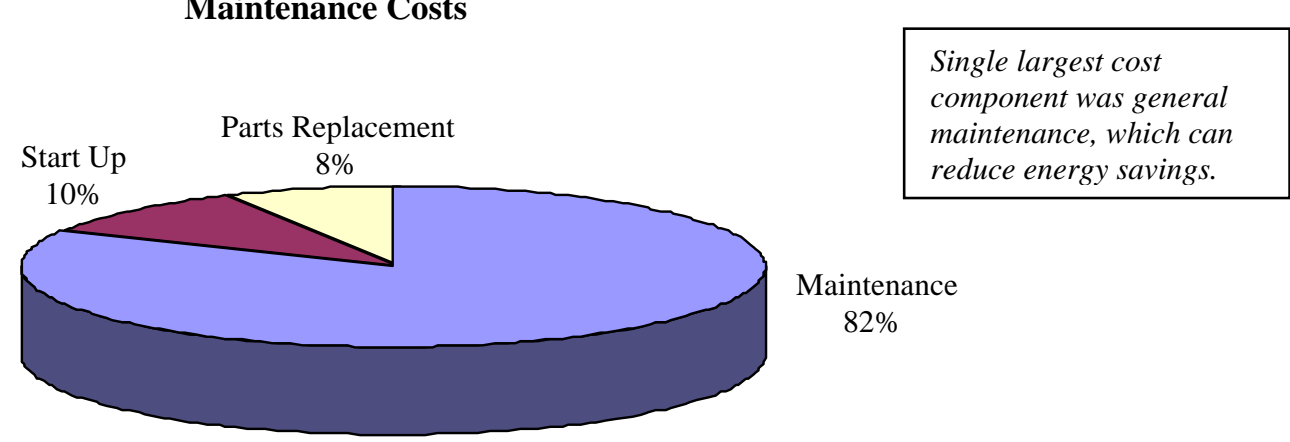

The single largest cost of running the fuel cell over the five-year period was general maintenance cost (including labor and material) which totaled approximately \$165,000. 
Year two of operating the fuel cell was the most expensive overall due to a combination of high general maintenance costs $(\$ 34,575)$ and the replacement of the Heat Exchanger HEX 400 and HEX 431 at a cost of $\$ 8,725.97$.

\section{Shut-downs}

The fuel cell was shut down a total of 48 times from July 1999 - June 2004. Not surprisingly, the largest number of shut-downs (16) was during the first year of operation. During year 2 the number of shut-downs decreased significantly to four.

Year 3 brought a 70\% increase in shut-downs - a total of 13. Eight of the thirteen shutdowns during year 3 were due to problems with fuel cell temperature element number 002. Temperature internal to the fuel cell exceeded set point values causing the system to shut down. It was a new problem not seen in previous years that the manufacturer believed was due to oxygen entering the fuel stream. The fuel compressor was overhauled to eliminate the possibility of it introducing air into the fuel train. The cubic feet per hour of air delivered to the carbon beds were adjusted to the minimum needed for H2S removal.

There were 8 shut-downs in Year 4 and 7 shut-downs in Year 5 of the fuel cell operation. Five of the shut-downs over the two-year period were due to loss of UPS; installation of a new battery in the UPS has cleared up this problem.

\section{Lessons Learned}

The following lessons learned are a direct result of operating and maintaining the fuel cell over the last five years:

- Maintenance costs are fairly significant and substantially negate power savings;

- The fuel cell is an extremely complex piece of equipment requiring a very knowledgeable staff;

- Power output diminishes over time;

- Temperature of the fuel cell cooling water loop is insufficient to allow efficient capture of waste heat for digester heating;

- Standby power is effectively provided; and

- Treatment of the digester gas (gas conditioning) is important and has its associated costs (power, materials, and labor).

\section{Microturbines}

While the Portland Bureau of Environmental Services had been innovative in using digester gas as an energy source, some of the gas was still burned in flares at the site. Since the flared gas was wasting a potential source of renewable energy, co-generation based on gas turbines was deemed a further step in the City's sustainable development effort.

In April of 2003, the Bureau of Environmental Services purchased and installed four, $30 \mathrm{KW}$, digester gas fueled, Capstone microturbines at the Columbia Boulevard Wastewater Treatment Plant. These microturbines would use the "biogas", flared off 
methane gas, generated by the sewage treatment process as a free fuel to produce energy for the treatment facility. Cogeneration through use of the microturbines would maximize use of the digester gas, satisfy plant heating needs, and reduce dependence on utility supplied electrical energy. The cost of the microturbines was $\$ 309,000$.

It was anticipated that the four microturbines together would generate $120 \mathrm{~kW}$ and generate enough electricity to operate the entire plant. If $85 \%$ utilization is made of the system, 819,000 KWhr of energy will be generated each year. Reusing methane to produce energy improves air quality and reduces operating costs at the sewage treatment plant. The microturbines were estimated to save $\$ 61,000$ a year in electricity costs.

The Bureau of Environmental Services, City of Portland, had several different objectives in installing the microturbines including:

- Reduction of power costs

- Utilization of abundant onsite biogas as fuel

- Reduction of emissions formed during biogas combustion

- Utilization of waste heat to power facility operations

- Effectively demonstate the use of clean green power at a wastewater treatment facility

- Provide back-up power in power outages

Installation and Cost of the Microturbines

The four microturbines were installed in April of 2003 and were completely operational by June 2003. The system design was based on a successful operation that was installed in San Elijo, CA.

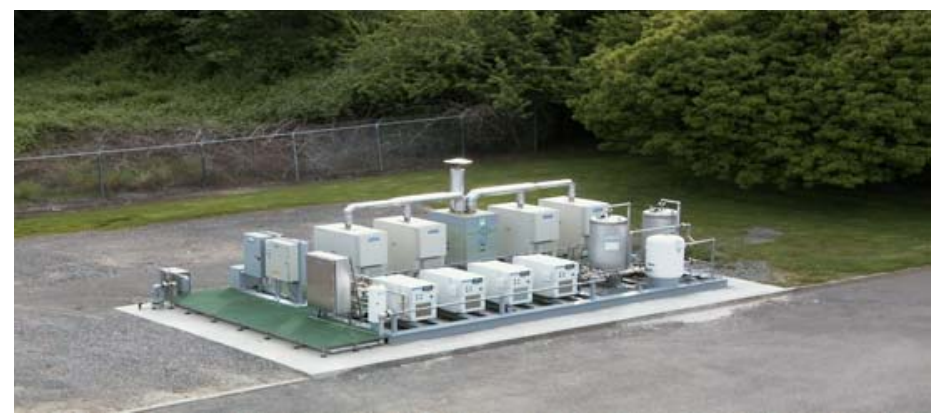

4 Capstone 30 kW Microturbines with Central Heat Recovery

The cost of the microturbines and ancillary equipment as well as the installation was reduced by approximately $10 \%$ due to the Oregon Building Energy Tax Credit program. 


\begin{tabular}{||c|c||}
\hline EQUIPMENT & COSTS \\
\hline $\begin{array}{c}\text { Turbines } \\
\text { Compressors } \\
\text { Heat Recovery } \\
\text { Gas Processing } \\
\text { Electrical }\end{array}$ & \\
\hline Installation Cost & $\$ 300,000$ \\
\hline TOTAL INITIAL COST & $\$ 46,000$ \\
\hline $\begin{array}{c}\text { Energy Rebate } \\
\text { (BETC passthrough) }\end{array}$ & $\$ 346,000$ \\
\hline NET COST & $\$ 37,000$ \\
\hline
\end{tabular}

The four units combined would produce $120 \mathrm{~kW}$. The per $\mathrm{kW}$ cost was $\$ 2,575$ after the BETC passthrough as compared with $\$ 2,883$ per $\mathrm{kW}$ without the energy credit.

\section{Testing, Monitoring, Analysis and Evaluation of Microturbine Project}

\section{Project Driver}

$\mathrm{NO}_{\mathrm{x}}$ emissions are of concern in Portland and many other large urban communities. Since Portland is an attainment area for ozone, the role of $\mathrm{NO}_{\mathrm{x}}$ in ozone formation and the potential for the area to become non-attainment inclines local regulators to focus on limiting $\mathrm{NO}_{\mathrm{x}}$ emissions. Each month the Columbia Boulevard Wastewater Treatment Plant flares approximately $2700 \times 10^{6} \mathrm{BTU}$ in digester gas. The process is estimated to produce 0.044 to 0.084 pounds of $\mathrm{NO}_{\mathrm{x}}$ per million BTU's flared.

$\checkmark \mathrm{No}_{x}$ emissions from microturbine combustion are projected at $0.005 \mathrm{lbs} / \mathrm{MBTU}$, or an 88 to 94 percent reduction compared to present emissions.

An estimate of 25-30 percent efficiency is the standard for generation of electricity by microturbines, thus the promise of significant improvement in the energy return per BTU of gas consumed.

\section{Results}

Emissions testing conducted in February 2005 by Horizon Engineering showed that the microturbines produce less NOx than the boilers or the flare combustors.

\begin{tabular}{|c|c|}
\hline OPTION & $\begin{array}{c}\text { NO }{ }_{\times} \text {EMISSIONS } \\
\text { (LBS/MILLION CUBIC FT. OF FUEL) }\end{array}$ \\
\hline Flaring & $0.044-0.084$ \\
\hline Reciprocating Engines & $1.22-2.09$ \\
\hline Turbine Engines (1000kW size) & 0.011 \\
\hline Microturbines (Capstone) & 0.005 \\
\hline Fuel Cell & 0.002 \\
\hline
\end{tabular}

Note that the fuel cell produced virtually no NOx. 


\section{Project Driver}

The City of Portland sewage collection system includes approximately 100 pump stations. Thirty-four of these are considered critical to public safety and are equipped with diesel generator units, from $60 \mathrm{~kW}$ to $350 \mathrm{~kW}$, to provide electricity in the event of a power failure. Back-up power operation is characterized by extended periods of no operation, short start-up cycles, long idle periods, and large instantaneous load swings associated with the starting and stopping of flooded suction pumps.

$\checkmark$ Suitability of microturbines for emergency power applications in heavy load conditions is not well established. The potential use of microturbines versus diesel as emergency back-up power at remote pump station location offers the possibility of cleaner burning, less energy-consuming, less costly and more reliable service to customers.

\section{$\underline{\text { Results }}$}

Testing of the start-up capability of the microturbines was completed. The microturbines take about 90 seconds to go from cold start to assume full load conditions. Occasionally, a single microturbine has to restart, which takes about 140 seconds. A comparable diesel engine generator takes about 30 seconds to assume full load. Applications typically require standby within 3-5 minutes. The microturbine and diesel appear to be equally effective in meeting plant standby requirements.

\section{Project Driver}

The Columbia Boulevard Wastewater Treatment Plant generates approximately $21.5 \mathrm{x}$ $10^{6} \mathrm{ft}^{3}$ of anaerobic digester gas a month, net (digester gas production less boiler usage to provide digester heat). The gas is approximately $60 \%$ methane, the remainder primarily $\mathrm{CO}_{2}$ with a heat content estimated at $600 \mathrm{BTU} / \mathrm{ft}^{3}$. In general, digester gas production at secondary treatment plants in this country may be estimated at about $1 \mathrm{ft}^{3} /$ capita/day, a byproduct of the reduction of sewage solids.

$\checkmark$ Given the expanding population of most U.S. cities, and the environmentally motivated trend toward the development of more efficient secondary treatments, anaerobic digester gas energy production or blended anaerobic digester gas and natural gas represents a possibility for a readily available renewable energy source present in most cities.

\section{$\underline{\text { Results }}$}

Testing of the anaerobic digester gas versus natural gas showed that:

- ADG has about $70 \%$ of the energy (heat value) of commercial natural gas;

- ADG can be successfully utilized in lieu of natural gas to fuel/operate engine generators (e.g., microturbines, internal combustion engines);

- The use of ADG results in decreased emissions as compared to natural gas; and

- ADG use results in less energy costs. 


\section{Project Driver}

Real time peak and daily $\mathrm{kW}$ production, run time, reliability, and operating cost data were gathered through an interface connection with the local utility, Portland General Electric. This will provided real time data as well as the opportunity to test software predictive ability in a real world operating setting.

\section{Results}

The webpage featuring the microturbine is currently being beta tested, and will be fully available shortly. The local electric company, Portland General Electric, is monitoring energy use of the microturbines through their connection with the wastewater treatment plant. Work continued on the communications interface with the plant SCAD system and development of view screens. PGE continues to collect real time operating data through their interface connection with the wastewater treatment plant. Below is a sample report detailing real time operating data compiled for the microturbines over a 12-month period? This data is based on only three fully functional microturbines; the fourth microturbine was off-line due to a fouled gas inlet.

\begin{tabular}{|c|c|c|}
\hline Historical Data Table & & \\
\hline \multicolumn{3}{|l|}{ Device : Micro Turbine _ CM } \\
\hline \multicolumn{3}{|l|}{ System: cbtp } \\
\hline Report Start Time: 2/15/2005 12:00:01 PM & Dbase Srvr: HORTEN & JSIOISMS3000 \\
\hline Report End Time: 2/15/2006 12:00:01 PM & History DSN: Info Mgr & r History SQL \\
\hline Report Generated on: 2/16/2006 11:48:51 AM & System DSN: Info Mgr & r System SQL \\
\hline Months & $\begin{array}{l}\text { Total mont } \\
\text { Kilowatt ho }\end{array}$ & $\begin{array}{l}\text { thly } \\
\text { ours }\end{array}$ \\
\hline February-05 & 6,926.7 & \\
\hline March-05 & $7,116.7$ & \\
\hline April-05 & $9,110.2$ & \\
\hline May-05 & $16,017.5$ & \\
\hline June-05 & $3,109.6$ & \\
\hline July-05 & $18,832.9$ & \\
\hline August-05 & $40,925.9$ & \\
\hline September-05 & $21,779.0$ & \\
\hline October-05 & $31,248.4$ & \\
\hline November-05 & $14,038.0$ & \\
\hline December-05 & $27,059.1$ & \\
\hline January-06 & $19,217.6$ & \\
\hline February 15,2006 & $6,215.9$ & \\
\hline MT Annual Kilowatt hours & $221,597.5$ & \\
\hline
\end{tabular}




\section{Percent of monthly power needs supplied}

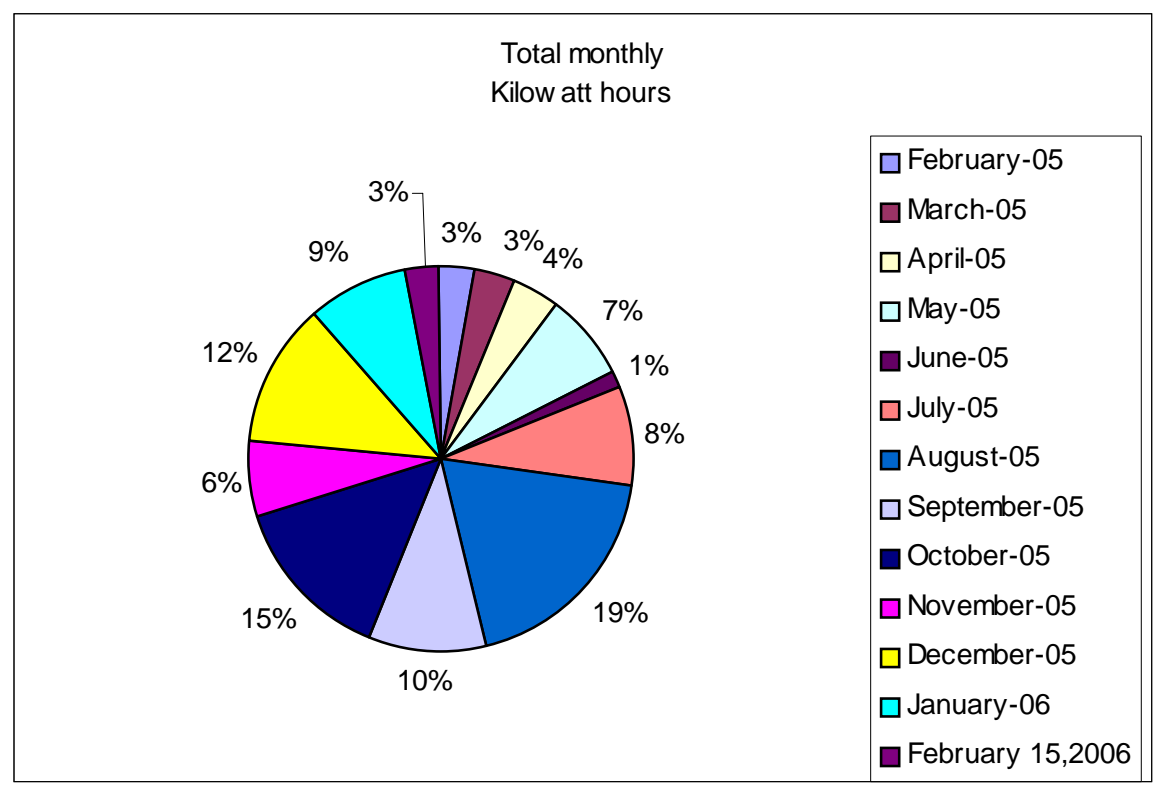

In August of 2005, the microturbines approached 50\% utilization. One hundred percent uptime would amount to $\sim 86,400 \mathrm{kWhr}$ per month.

\section{Operating History}

Installation of the four microturbines was completed on April 11, 2003, and start-up of all four units was completed on April 24, 2003. The microturbines ran reliability until August 2003 when a number of technical problems caused the microturbines to be shut down. City of Portland engineers working with Capstone and Applied Filter Technologies determined that the original installation had to be modified because the desiccant bed provided inadequate drying of the gas. A gas dryer was added to supplement the desiccant. In addition, the pressure drop in the carbon beds produced a negative gauge pressure in the fuel line going into the gas compressors. The original compressors were changed out in order to maintain a positive pressure, thereby eliminating the possibility of a leak creating an explosive air fuel mixture going into the hot compressors. The analysis and identification of the various technical issues; development of plans to resolve the situations; and coordination of ordering parts and equipment as well as coordinating the efforts of a team of diverse contractors was a long and frustrating period. The microturbines did not come back on line until November 2004 (the microturbines were down for 18 months). Since then three of the microturbines have operated consistently and reliably. The fourth unit was rebuilt by the manufacturer, but is still experiencing problems with its gas flow meter.

In light of all the technical issues, an evaluation was made of microturbines operating at four other wastewater treatment facilities using ADG. Commonly identified problems included:

- Water in the microturbines;

- Siloxane deposits; 
- Higher than expected costs for fuel preparation and maintenance;

- Need to find a cost effective gas pretreatment approach for specific application; and

- Problems with slow or non-responsive manufacturers and distributors.

Microturbines, like all emerging technologies, have had some early technical and reliability problems. However, as adjustments and technical improvements are made, microturbines will offer even greater benefits. Wastewater treatment plants using anaerobic digesters offer a unique opportunity to benefit from this technology.

\section{Task 2 - Regulatory Assistance Project/National Association of State Energy Officials Metrics/Verification Model for DG Guidelines}

\section{Project Overview}

The Regulatory Assistance Project (RAP) and the National Association of State Energy Officials (NASEO) worked together on this effort. RAP is a non-profit organization, formed in 1992, that provides workshops and education assistance to state public utility regulators on electric utility regulation. In addition, RAP principals have written and spoken extensively on many issues associated with industry restructuring, power sector reform, renewable resource development, demand-side management and green pricing. This project focused on building on prior DOE-sponsored work such as Making Connections and the Distributed Generation Collaborative to develop a model to evaluate individual guidelines developed by state and regional authorities as to their likely effect on the rate and extent of distributed generation deployment. This tool will not rank the guidelines, but will assess their effectiveness in meeting certain general objectives such as ease of permitting, method of assessing emissions and efficiency as well as environmental quality.

\section{Work Completed}

Initial research and data gathering conducted for development of the DG Policy Scoring Tool included:

- Developing a preliminary list of important factors by which state DG guidelines should be measured

- Developing a contact list of state government officials in a position to answer questions about state DG guidelines

- Began a series of interviews with state officials about DG guidelines and their outcomes. States included: Rhode Island, New Jersey, Massachusetts, Connecticut, Vermont, New Hampshire, Pennsylvania, Maryland, and the District of Columbia.

Following on successful work efforts with NREL (Making Connections) and RAP's own Distributed Resources Policy Series, RAP developed a DG Policy Scoring Tool that enables a state to assess the likely effect of its regulations pertaining to distribution generation. Barriers and enabling elements of the states' regulations are identified. 
Many factors and suggestions at all levels (National, state, regulatory agencies, nonprofits, and environmental groups) were considered in the development of this Model.

The new software tool, the DG Policy Scoring Tool, allows state and territory energy offices to consider critical DG policies as a whole package, rather than in an isolated, or ad hoc fashion. The DG Policy Scoring Tool is specifically intended to assist state regulators and policy makers to assess the strengths and weakness of their existing CHP and related policies.

The tool was prepared in Virtual Basic and creates a simple interface with a user knowledgeable in the relevant policies in the state. A user guide and the DG Policy Scoring Tool are available on-line at http://www.raponline.org/Feature.asp?select=83\&Submit1=Submit. RAP communicated with several state energy office officials about the tool and incorporated their feedback, as appropriate, into the final version. A presentation was given at the NASEO annual meeting on September 13, 2005, and the beta test version of the tool was demonstrated to several NASEO members and other individuals at that meeting. NASEO provided CDs of the tool to all its members. RAP has also provided individual technical assistance as requested to several NASEO members.

The software tool is designed as an interactive interview system; it is category driven with some conditional questions. Points are allocated for each answer and help screens are available throughout the program to guide and assist the user. Prior to using the program, it is recommended that a copy of any rules or regulations that the particular state utility and environmental regulators may have adopted that would impact the deployment of Distributed Generation be available. These might include the following:

- Utility Commission Rules:

- PURPA Rules

- Distributed Generation Interconnection Standards

- Distributed Generation Standard Contracts

- Individual Utility tariffs that address customer-owned generation, including standby and backup rates

- Environmental Rules such as: Emissions standards for Distributed Generation

System users will be able to see in which policy areas their efforts are supporting DG and in which policy areas more should be done. Policy areas include: interconnection, rates, environment, planning, revenue, outreach, and procurement. The tool also provides a page of weblinks to DOE and NREL sites on distributed generation.

This tool provides a clear indicator of policy suitability for DG, and can indicate how the policy environment should change to improve DG prospects. 
The following are sample screens from the software tool.

DG Policy Tool (Policy Score Screen)

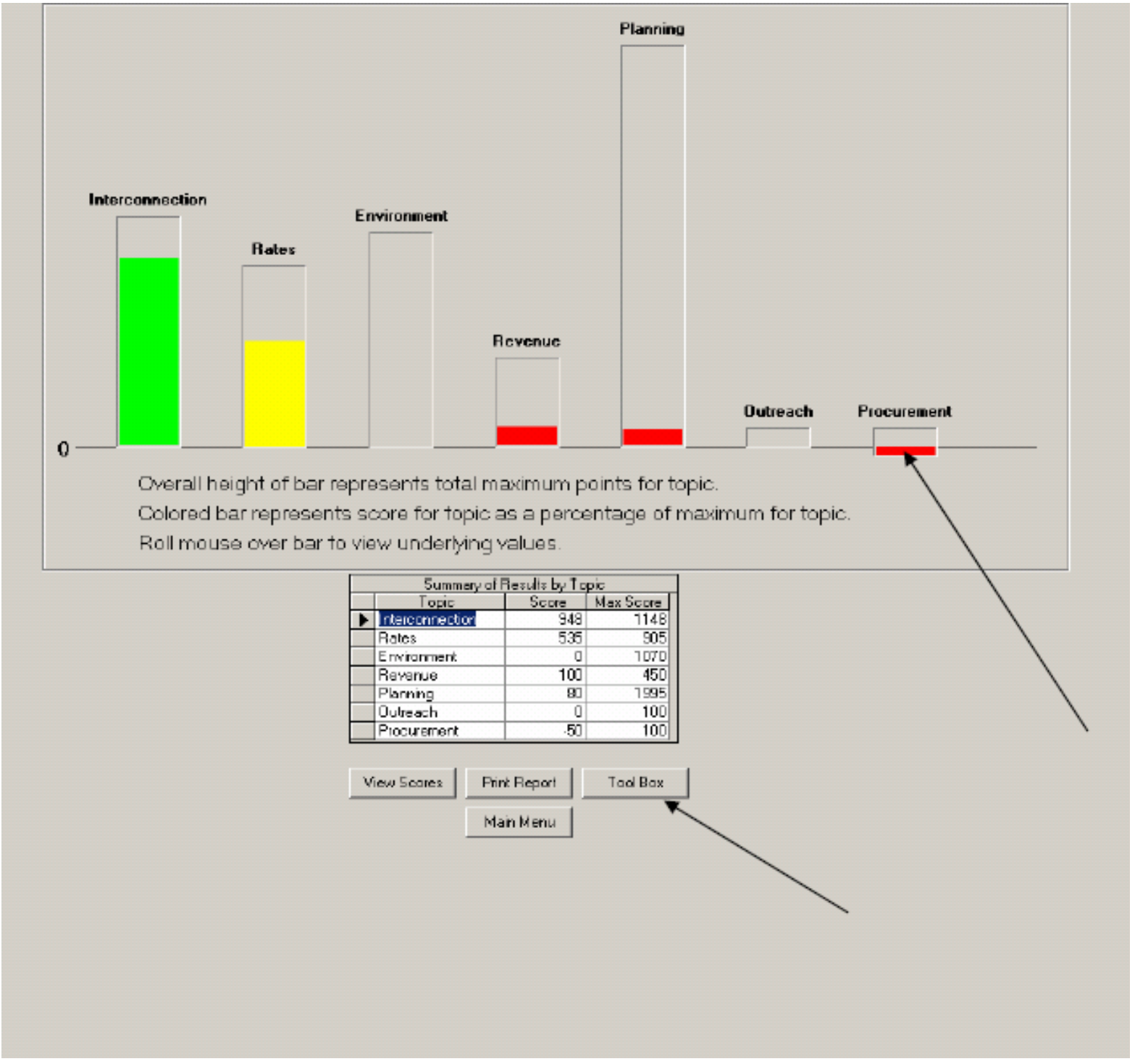


Example of Interview Format Screen

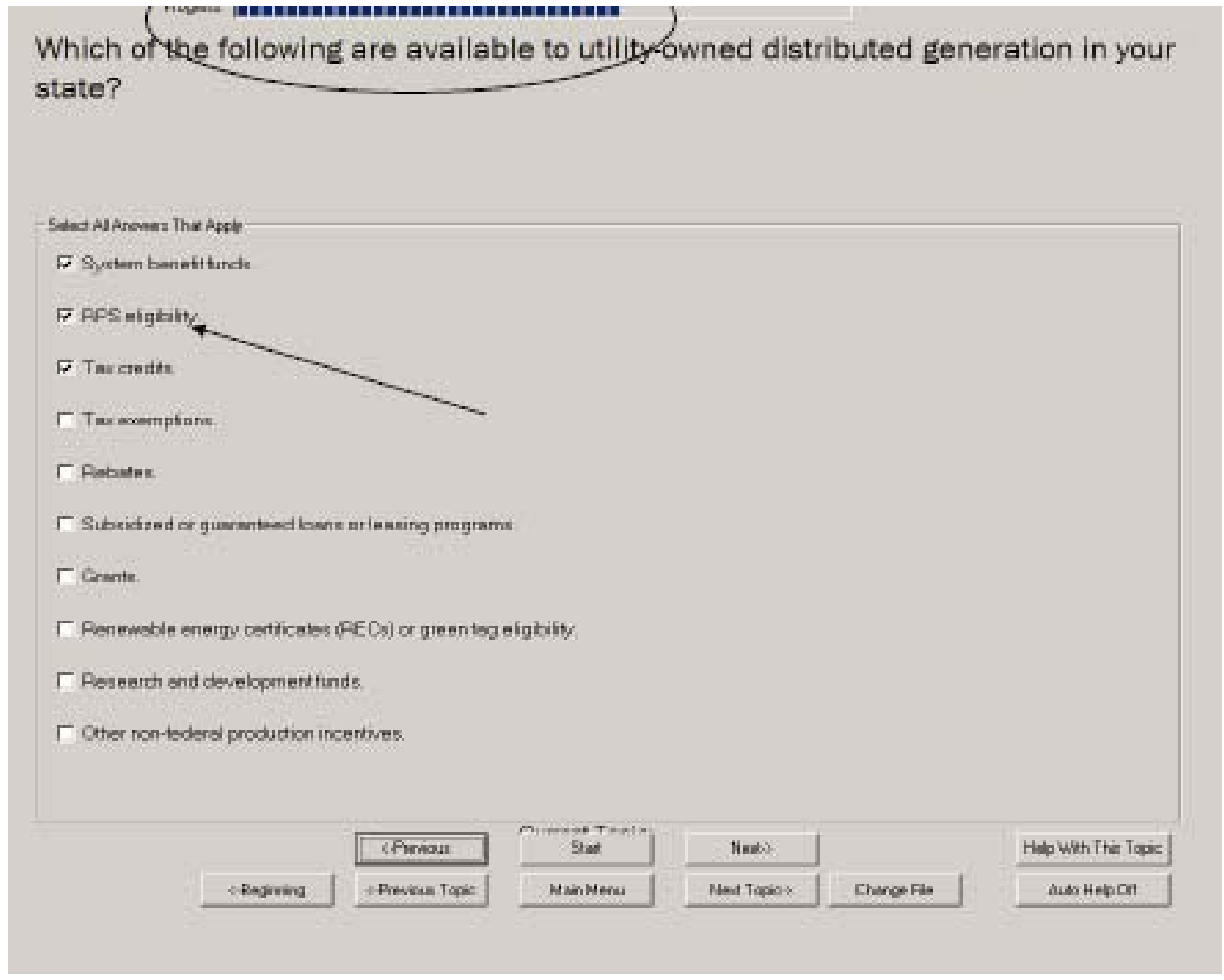

\section{Task 3 - Regulatory Assistance Project and National Association of State Energy Officials Northeastern Transmission/Siting Data Research}

\section{Project Overview}

Traditional solutions to transmission system congestion --building new power lines-- are very challenging and expensive in nearly every case. Large central station power generation construction can also address transmission grid constraints, but these kinds of facilities are often incompatible with the local high population density in urban areas. These constraints form the basis for increased attention to building non-traditional generation proximate to the point of use -- distributed generation. 
A serious research and data gap exists in the areas of transmission constraints, interconnect barriers, and strategic placement of DG in urban areas of the Northeast. Questions must be addressed, such as: Is there a public policy reason to target distributed generation to particular geographic areas, corresponding to providing the greatest benefits to congestion mitigation efforts, and if there is a good reason, can a distinct set of sound guidelines and incentives for this targeting be developed and applied by state and regional planning and industrial stakeholders? These questions and issues were addressed thorough additional research and analytical work in the following areas:

- Assembling information on transmission system constraints gathered from the North American Electric Reliability Council, ISO-New England, utilities and other available sources.

- Comparing this information with maps of available gas supply and any other relevant geographical information that may influence the pace of deployment of distributed generation.

\section{Work Completed}

The Regulatory Assistance Project researched, analyzed and assembled information on transmission system constraints covering three regional areas of the Northeast U.S. where electric power grid is managed by three system operators - ISO-New England, the New York ISO, and the PJM Interconnection.

Distributed generation can be an important resource for the electric transmission system, just as large-scale generation is. This is especially the case where the transmission system is congested. "Congestion occurs when available, low-cost energy cannot be delivered to all loads because of limited transmission capabilities. When the least cost available energy cannot be delivered to load in a transmission-constrained area, higher cost units must be dispatched in this constrained area to meet that load. ${ }^{1}$ The result is that the price of energy in the constrained area is higher than elsewhere because of the transmission limitations." 2

Congestion does not happen all the time. Customer load and available generation must be in certain conditions for congestion to occur. Higher load, especially in the cities, is a usual precursor to congestion.

\footnotetext{
${ }^{1}$ This is referred to as dispatching units out of economic merit order. Economic merit order is the order of all generator offers from lowest to highest cost. Congestion occurs when loadings on transmission facilities mean that the next unit in merit order cannot be used and that a higher cost unit must be used in its place.

${ }^{2}$ PJM State of the Market Report 2004, pg 36.
} 


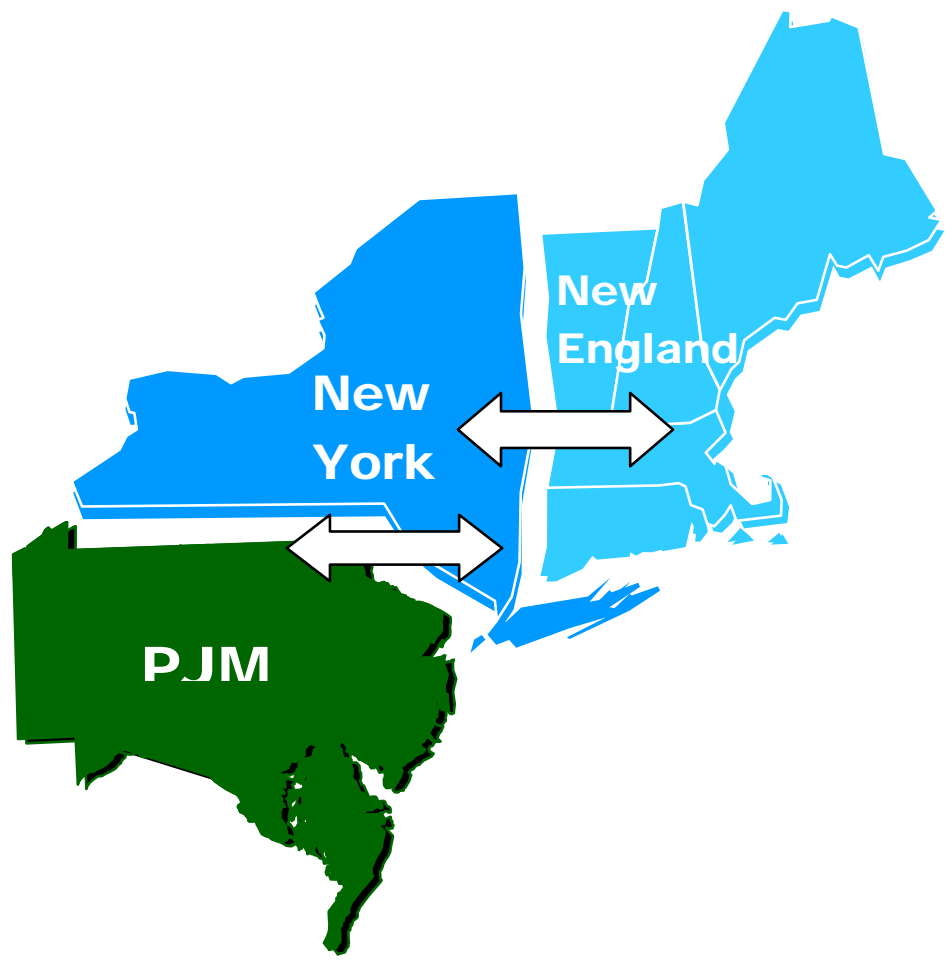

Three regional systems in the Northeast/Mid-Atlantic U.S. discussed in this report

System operators manage congestion in real time. They can ramp down output from less expensive but remote generation, and turn on units near the load that are more expensive. They can also open or close circuits that take power lines out of service or back on line.

There are two basic ways to solve system congestion. One is to increase transmission capacity to allow remote generation to flow to the congested place. Existing transmission lines can be modified to carry more power, additional circuits can be placed in a right-ofway, or whole new transmission corridors can be created. The other is to reduce the demand on the transmission system and the pressure for power to flow over the existing transmission capacity. Lightening the load on the system can be accomplished with local generation, energy efficiency, or demand response.

While it is clear that distributed generation and other distributed resources are reliability resources and can address system congestion, efforts to solve congestion rarely feature these resources. Regulatory reform is underway in many states and regions to address this deficiency.

In each of the three regions, there are limitations in power flows, or congestion.

Generally, these conditions are caused by persistent load growth in the cities, while power generation is most easily accomplished in more rural places or where natural resources, like coal, are found. While this has always been the case, circumstances are coalescing to increase congestion and reliability concerns. For example: 
- Significant transmission built decades ago to accommodate large coal and nuclear generators are finally approaching or meeting their limits, at least during some hours. Many states have seen few transmission siting cases in recent years.

- Building new transmission can be expensive, and additional challenges come from environmental limits and conversion of countryside to suburban development and expansion of cities pressing in on right-of-way corridors. Transmission companies can be reluctant to start this process. Permitting or construction delays sometimes ensue.

- The ability to site natural gas fired generation in or near cities due to favorable air quality characteristics has reduced the frequency of congestion from what it would have been if the practice had persisted of building rural, large generating stations, which was typical in the 1970s and 80s. But increasing natural gas prices and a desire to maintain a diverse fuel supply indicate that the pace of natural gas generation construction near cities may slow in the coming years.

- Demand side resource are under-utilized and are not generally used to address congestion and reliability concerns.

There is increasing attention on the cost of congestion and policy solutions to address it. However, distributed generation is generally under-represented in these discussions.

The Northeast U.S. has modeled different ways to introduce distributed generation to address congestion, including the PJM Market Window, the Southwest Connecticut emergency resource solicitation, and the deployment activity in New York. Engaging utilities to be consistently active partners in DG deployment for congestion relief and reliability support would add significant momentum.

Obstacles to this step change in utility support for DG include:

- the standard planning and engineering practices of many utilities which tend to look at power flows as one-way to the customer, not two-way with the customer as a resource;

- the connection between utility profits and sales that does not sufficiently reward more efficient service;

- interconnection and rate practices that add unreasonable burdens to the distributed generation project balance sheet; and

- technology which is still a little too exotic or complex for many customers.

A state where utilities and system operators actively seek distributed generation and other distributed resources as solutions to system congestion and reliability concerns would lead to a dramatic increase in deployment.

As a second part of the task, information was gathered on available natural gas supply for the three regional areas to determine the potential impact of natural gas supply on the deployment of distributed generation. 
While overall firm sales growth has led to physical improvements in the natural gas pipeline system, certain limitations to natural gas availability for distributed generation persist:

- Natural gas is still not available in many areas, primarily less populated areas;

- Significantly more gas is purchased with interruptible contracts. Interruptions for non-firm gas appear to have increased a tick in probability.

Fortunately, while availability limitations may influence the choices of some customers, there remain ample reasons for customers to consider and choose distributed generation independent of natural gas availability

- Natural gas is available in the population centers in the northeast. Facilities are in place to maintain high reliability for firm gas deliveries. In these locations and many rural areas in between are the lion's share of distributed generation opportunities and the full range of applications.

- Propane can also be used for most of the same applications as natural gas and is being used for DG in areas where natural gas is not available.

The recent step increase and volatility of natural gas prices has caused a pause in distributed generation development. Since electric rates in many Northeast states are capped, or do not vary the short-term costs of fuel, the business case for distributed generation has, at least temporarily, gotten more tenuous with narrowing "spark spreads." As the increased price of natural gas finds its way through to ultimate electric consumers, it is likely that the business case will revert to one more similar to what prevailed earlier this decade.

From the broadest of perspectives, the availability of natural gas is a far lesser influence on the deployment rate of distributed generation, as compared with factors such as regulatory incentives for or against DG, applicability of distributed generation and CHP system technology to an increasing proportion of end uses, and the price of natural gas. This is the case today and is likely to continue for some decades.

NASEO and its members benefited from RAP's participation in a number of other topical related groups such as:

- The Northeast Combined Heat and Power Initiative - an ad hoc broadstakeholder group with support from the Gas Technology Institute to be the focus of policy developments promoting CHP in New England and New York

- Mid-Atlantic Energy Working Group (MADRI) - a group organized by PJM with support from the Department of Energy. The key purpose of this group is to address key policies that would make a difference in the deployment of customer electric resources, including distributed generation

- Emergence of regional CHP initiatives, such as mentioned above, as well as Gridwise (Department of Energy and industry sponsored) and SmartGrid (EPRI sponsored) have created excellent and accessible resources for state energy offices and others to obtain information about the growing prospects for DG application. 


\section{Conclusion}

All three of these tasks, taken together, help paint a picture of the future of distributed generation in the U.S. - in terms of the increasing need for the technology, current operational reliability in certain situations, and factors affecting distributed generation deployment. 